\title{
Optimization of Biomass Production with Copper Bioaccumulation by Yeasts in Submerged Fermentation
}

\author{
Andréa Haruko Arakaki ${ }^{1}$, Luciana Porto de Souza Vandenberghe ${ }^{1 *}$, Vanete Thomaz \\ Soccol $^{1}$, Ryu Masaki ${ }^{1}$, Ernani Francisco da Rosa Filho ${ }^{2}$, Alexsandro Gregório ${ }^{2}$ and Carlos \\ Ricardo Soccol ${ }^{1}$ \\ ${ }^{1}$ Departamento de Engenharia de Bioprocessos e Biotecnologia; Universidade Federal do Paraná; 81531-990; \\ Curitiba - PR - Brasil. ${ }^{2}$ Laboratório de Pesquisa Hidrogeológicas; Universidade Federal do Paraná; 81531-990; \\ Curitiba - PR - Brasil
}

\begin{abstract}
The objective of this work was to study the production of biomass with copper bioaccumulation in submerged fermentation using sugarcane molasses. Candida pelliculosa BARU 05 isolated from Baru (Dipteryx alata) was selected for its good capacity to accumulate the copper. Fermentation was carried out using the medium composed by sugarcane molasses at $5{ }^{\circ}$ Brix enriched with $(\mathrm{g} / \mathrm{L}) \mathrm{CuSO}_{4} .5 \mathrm{H}_{2} \mathrm{O} 0.1$; yeast extract, 10.0; $\left(\mathrm{NH}_{4}\right)_{2} \mathrm{SO}_{4}, 5.0$; $\mathrm{KH}_{2} \mathrm{PO}_{4}, 5.0 \mathrm{MgSO}_{4}$, 0.5, inoculum $10 \%$ of total volume $(100 \mathrm{ml}), \mathrm{pH} \mathrm{6.0,} \mathrm{and} \mathrm{incubation} \mathrm{at} 30{ }^{\circ} \mathrm{C}, 120 \mathrm{rpm}$ for $120 \mathrm{~h}$. After three steps of optimization an uptake of $95.04 \%$ and $13.397 \mathrm{~g} / \mathrm{L}$ biomass were obtained. The kinetics of copper bioaccumulation and biomass production was followed in a 10-liter bioreactor in a batch and fed-batch fermentation which showed copper accumulation of 91.98 and $100 \%$, respectively, and biomass production of $38.85 \mathrm{~g} / \mathrm{L}(24 \mathrm{~h})$ and $57.54 \mathrm{~g} / \mathrm{L}(48 \mathrm{~h})$, respectively.
\end{abstract}

Key words: Bioaccumulation, baru, yeast, copper, sugarcane molasses

\section{INTRODUCTION}

There are many economic benefits that are related to the discovery of potentially exploitable microorganisms in biotechnological processes, including the production of new therapeutic agents and antibiotics, probiotics, chemicals, enzymes and polymers for industrial applications (Celligoi, et al., 1997; Colwell, 1997; Hunter 1998; Angel, et al., 2000, Rodrigues, et al., 2009, Alberton et al., 2009, Sella et al., 2009). Microelements, also called trace elements, are present in small amounts in the body and are expressed in $\mathrm{mg} / \mathrm{kg}$ or $\mathrm{ppm}$ (parts per million) of body weight (Ortolani,
2002). The interest of trace elements appears, mainly to replace, or at least reduce, the current indiscriminate use of antibiotics and chemotherapeutic agents used in the animals, which can be harmful to the consumers and the environment (Hisano et al., 2007).

Copper is present in cellular respiration, bone formation, tissue development and pigmentation. It is also an essential component of several metalloenzymes (Macdowell, 1992; Vasquez et al., 2001; Ortolani, 2002; Marques et al., 2003). Moraes et al., (1999) and Sucupira et al., (2007) reported that the most common deficiencies of trace elements in sheep and cattle in Brazil were

*Author for correspondence: lvandenberghe@ufpr.br 
related to the deficit in copper and cobalt. The role and importance of copper in animal metabolism are well known (Vasquez et al., 2001). The gain of weight in some ruminants is related to the presence of copper in the diet, which is essential for their development (Hauschild et al., 2008).

Molasses is a co-product of sugar production, both from sugar beet and from sugar cane, and is the runoff syrup from the final stage of sugar crystallization process from which further recovery of sugar is uneconomical. Molasses could be used in different biotechnological processes as substrate since its composition favors the development of different microorganisms (Cazetta et al., 2007; Valduga et al., 2007, Roepecke et al., 2011). The composition of sugarcane molasses is $73-95 \%$ total sugars, $70-91 \%$ sucrose and $2-4 \%$ glucose (Mantellato, 2005).

This work aimed to develop a bioprocess for yeast biomass production with copper bioaccumulation in submerged fermentation using sugarcane molasses as substrate.

\section{MATERIALS AND METHODS}

\section{Microorganisms}

Eleven yeasts strains isolated from Baru (Dipteryx alata) were tested. One of them, identified as Candida pelliculosa Baru 05, showed good copper bioaccumulation capacity and was selected for biomass production.

\section{Optimization of process conditions}

For the optimization of biomass production with copper bioaccumulation, the chemical composition of the fermentation medium was studied in the first step. Factorial experimental designs were used for the screening and determination of the main significant components of the medium (Rodrigues and Iemma, 2005). Two responses were analyzed, which included biomass production $(\mathrm{g} / \mathrm{L})$ and copper bioaccumulation yield (\%) using STATISTICA 7.1 software (StatSoft, Tulsa, OK, USA).

Initial experiments were performed at laboratory scale in Erlenmeyer flasks of $250 \mathrm{~mL}$. Candida pelliculosa BARU 05 was used for biomass production with copper accumulation. Inoculum was prepared in $250 \mathrm{ml}$ Erlenmeyer flasks that were incubated at $30^{\circ} \mathrm{C}$ and $120 \mathrm{rpm}$ till a cell concentration of $1 \times 10^{8}$ cells $/ \mathrm{mL}$ was achieved. The medium comprised sugarcane molasses at $5^{\circ}$ Brix and $(\mathrm{g} / \mathrm{L})$ yeast extract, $10 ;\left(\mathrm{NH}_{4}\right)_{2} \mathrm{SO}_{4}, 5.0$; $\mathrm{KH}_{2} \mathrm{PO}_{4}, 5.0 ; \mathrm{MgSO}_{4}, 0.5$ and copper sulphate 0.1 (Stehlik-Thomas et al., 2004). Inoculum rate was $10 \%$ of total volume $(100 \mathrm{~mL})$. Physical biomass production was previously optimized (data not shown) and conditions were defined as follows: temperature, $30{ }^{\circ} \mathrm{C}$; initial $\mathrm{pH}, 6.0$; agitation, 120 rpm; cultivation time; $120 \mathrm{~h}$.

Studies were carried out to select the best nitrogen source among urea, $\mathrm{NH}_{4} \mathrm{Cl}, \mathrm{NH}_{4} \mathrm{NO}_{3},\left(\mathrm{NH}_{4}\right)_{2} \mathrm{SO}_{4}$ and $\left(\mathrm{NH}_{4}\right)_{2} \mathrm{HPO}_{4}$ at a concentration equivalent to the nitrogen content of $1 \mathrm{~g} / \mathrm{L}$ of urea. Subsequently, a $2^{7-4}$ incomplete factorial design was used in which seven components $\left(\left(\mathrm{NH}_{4}\right)_{2} \mathrm{SO}_{4}\right.$, $\left(\mathrm{NH}_{2}\right)_{2} \mathrm{CO},\left(\mathrm{NH}_{4}\right)_{2} \mathrm{HPO}_{4}, \mathrm{KH}_{2} \mathrm{PO}_{4}, \mathrm{CaCl}_{2}, \mathrm{MgSO}_{4}$ and $\left.\mathrm{Fe}_{2}\left(\mathrm{SO}_{4}\right)_{3}\right)$ were tested to determine their effect on biomass production $(\mathrm{g} / \mathrm{L})$ and copper bioaccumulation (\%) as shown in Table 1.

The next step of optimization employed a $2^{4-1}$ fractional factorial experimental design that was used to study the levels of significant variables (Table 2), including $\left(\mathrm{NH}_{4}\right)_{2} \mathrm{SO}_{4},\left(\mathrm{NH}_{4}\right)_{2} \mathrm{HPO}_{4}$, $\mathrm{CaCl}_{2}$ and ${ }^{\circ} \mathrm{Brix}$.

Table $1-2^{7-4}$ incomplete factorial design with 3 central points - variables and levels $(\mathrm{g} / \mathrm{L})$.

\begin{tabular}{cccccccc}
\hline Level & $\left(\mathbf{N H}_{\mathbf{4}}\right)_{\mathbf{2}} \mathbf{S O}_{\mathbf{4}}$ & Urea & $\left.\mathbf{( N H}_{\mathbf{4}}\right)_{\mathbf{2}} \mathbf{H} \mathbf{H O}_{\mathbf{4}}$ & $\mathbf{K H}_{\mathbf{2}} \mathbf{P O}_{\mathbf{4}}$ & $\mathbf{C a C l}$ & $\mathbf{M g S O}$ & $\mathbf{F e}_{\mathbf{2}}\left(\mathbf{S O}_{\mathbf{4}}\right)_{\mathbf{3}}$ \\
\hline-1 & 0 & 0 & 0 & 0 & 0 & 0 & 0 \\
0 & 1 & 0.5 & 1 & 1.25 & 0.065 & 0.25 & 0.05 \\
+1 & 2 & 1 & 2 & 2.5 & 0.13 & 0.5 & 0.1 \\
\hline
\end{tabular}

Table 2 - $2^{4-1}$ incomplete factorial design - variables and levels.

\begin{tabular}{ccccc}
\hline Level & $\left(\mathrm{NH}_{4}\right)_{2} \mathrm{SO}_{4}, \mathrm{~g} / \mathrm{L}$ & $\left(\mathrm{NH}_{4}\right)_{2} \mathrm{HPO}_{4}, \mathrm{~g} / \mathrm{L}$ & $\mathrm{CaCl}_{2}, \mathrm{~g} / \mathrm{L}$ & ${ }^{\circ}$ Brix \\
\hline-1 & 2 & 2 & 0.13 & 5 \\
0 & 3 & 3 & 0.26 & 7.5 \\
+1 & 4 & 4 & 0.52 & 10 \\
\hline
\end{tabular}


The third step of optimization tested the influence of ${ }^{\circ}$ Brix and $\left(\mathrm{NH}_{4}\right)_{2} \mathrm{SO}_{4}$ on copper uptake $(\%)$ and biomass production (g/L). In this case, a Rotational Central Composite Experimental Design was employed (Table 3). $\mathrm{CaCl}_{2}$ showed a positive influence for this process, however, it was tested separately at different concentrations to determine whether or not it was significant (data not shown).

Table 3 - Rotational central composite experimental design - variables and levels.

\begin{tabular}{ccc}
\hline Level & $\left(\mathbf{N H}_{\mathbf{4}}\right)_{\mathbf{2}} \mathbf{S O} \mathbf{O}_{\mathbf{4}}, \mathbf{g} / \mathbf{L}$ & Brix \\
\hline-1.41421 & 0.59 & 3.96 \\
-1 & 1 & 5 \\
0 & 2 & 7.5 \\
1 & 3 & 10 \\
1.41421 & 3.41 & 11.03 \\
\hline
\end{tabular}

Kinetics of biomass production with copper bioaccumulation in 10 liter bioreactor - Batch and Fed-Batch operation

In these studies, a 10 liter Bioflo ${ }^{\circledR} 110$ bioreactor was used with 5 -L medium. Fermentation was carried out using the medium with initial $\mathrm{pH} 6$, inoculum $7.5 \%(\mathrm{v} / \mathrm{v})$ and incubation at $30^{\circ} \mathrm{C}$ for $120 \mathrm{~h}$ for batch experiments. Agitation varied with the dissolved oxygen content at $30 \%$, which was controlled automatically. All the experiments were performed in duplicate. Sugarcane molasses was supplemented with $2 \mathrm{~g} / \mathrm{L}$ of $\left(\mathrm{NH}_{4}\right)_{2} \mathrm{SO}_{4}$ and $3 \mathrm{~g} / \mathrm{L}$ of $\left(\mathrm{NH}_{4}\right)_{2} \mathrm{HPO}_{4}$. Fed-batch fermentation was conducted with the same conditions of the batch fermentation. However, according to the sugar consumption, the bioreactor was fed once with sugarcane molasses after 20 hof fermentation. After the fermentation, the medium was centrifuged at $4000 \mathrm{rpm}$ for 10 minutes (Roepecke et al., 2011) and the analyses were carried out.

\section{Determination of copper and produced biomass}

The concentration of copper in the supernatant was determined after digestion with nitric acid and oxygen peroxide, according to the AOAC method (1997). Copper concentration in the solution was performed in an atomic absorption spectrometry, Varian Model AA spectrae 100-200 (Eaton et al., 1995). Copper that was in the supernatant and the amount of copper in the biomass were determined by the indirect method, by subtracting the copper concentration of the supernatant $\left(\mathrm{C}_{\mathrm{SOB}}\right)$ from its initial concentration in the fermentation medium $\left(\mathrm{C}_{0}\right)$ (Dönmez and Asku, 1999).

Cell biomass produced during the fermentation was determined by drying the material and determination of the dry weight (Roepecke et al.,, 2011). The content of reducing and total sugars was determined by the methods of Phenol-Sulfuric and Somogyi-Nelson (Nelson, 1944).

\section{RESULTS AND DISCUSSION}

\section{Effect of nitrogen source on copper bioaccumulation}

The effect of different nitrogen sources (urea, yeast extract, ammonium sulfate, ammonium citrate and ammonium nitrate) on biomass production of Candida pelliculosa BARU 05 and copper bioaccumulation was studied. Best results were found with urea $(1 \mathrm{~g} / \mathrm{L})$, which showed $84.92 \%$ bioaccumulation of copper. This source of nitrogen also contributed for good biomass production $(7.55 \mathrm{~g} / \mathrm{L})$, followed by yeast extract $(6.61 \mathrm{~g} / \mathrm{L})$.

However, control with no nitrogen source provided a biomass production of only $0.225 \mathrm{~g} / \mathrm{L}$. This showed that the, molasses, which was diluted to 5 Brix, needed supplementation of nitrogen, since the aim of this work was to increase the biomass production by yeast with high copper bioaccumulation.

\section{Selection of copper concentration}

Before starting the optimization of medium composition, the toxic concentration of copper on C. pelliculosa BARU05 was tested by varying the concentration of $\mathrm{CuSO}_{4} .5 \mathrm{H}_{2} \mathrm{O}$ in the medium $(0.1$ to $1 \mathrm{~g} / \mathrm{L})$. The increasing concentration of copper sulphate influenced significantly the biomass production and yield of bioaccumulation of copper. With $1 \mathrm{~g} / \mathrm{L}$ of copper sulphate, the biomass production decreased by $45.5 \%$ and bioaccumulation of copper was $92.65 \%$. This showed that the concentration of copper sulphate 
should be fixed at low values $(0.1 \mathrm{~g} / \mathrm{L})$. Gönen and Aksu (2008) and Stehlik-Thomas et al., (2004) found that high levels of copper sulfate in the fermentation process resulted in the decrease in copper bioaccumulation due to the toxicity effect. Thus, the concentration of $0.1 \mathrm{~g} / \mathrm{L}$ copper sulfate was chosen for further studies.

First step of optimization of chemical composition of the medium - Incomplete factorial design $2^{7-4}$ with three central points

Table 4 presents the results of the study of the effect of seven variables (concentration of different components) on biomass production with copper bioaccumulation, which were $\left(\mathrm{NH}_{4}\right)_{2} \mathrm{SO}_{4}$, urea, $\left(\mathrm{NH}_{4}\right)_{2} \mathrm{HPO}_{4}, \mathrm{KH}_{2} \mathrm{PO}_{4}, \mathrm{CaCl}_{2}, \mathrm{MgSO}_{4}$ and $\mathrm{Fe}_{2}\left(\mathrm{SO}_{4}\right)_{3}$. The highest yield of copper bioaccumulation by $C$. pelliculosa BARU05 was $99.31 \%$ with a biomass production of $6.18 \mathrm{~g} / \mathrm{L}$ (experiment 6). In this experiment, $\left(\mathrm{NH}_{4}\right)_{2} \mathrm{SO}_{4}$, $\left(\mathrm{NH}_{4}\right)_{2} \mathrm{HPO}_{4}$ and $\mathrm{CaCl}_{2}$ were present in the middle.

Pareto chart (Fig. 1) showed that the $\mathrm{CaCl}_{2}$ was the only significant variable on copper bioaccumulation by $C$. pelliculosa BARU05.

Table 4- Copper bioaccumulation and biomass production during optimization of chemical factors $-2^{7-4}$ incomplete factorial design with 3 central points.

\begin{tabular}{|c|c|c|c|c|c|c|c|c|c|}
\hline \multirow{2}{*}{ Experiment } & \multicolumn{7}{|c|}{ Independent Variables } & \multicolumn{2}{|c|}{$\begin{array}{l}\text { Response } \\
\text { Variables } \\
\end{array}$} \\
\hline & $\left(\mathrm{NH}_{4}\right)_{2} \mathrm{SO}_{4}$ & Urea & $\left(\mathrm{NH}_{4}\right)_{2} \mathrm{HPO}_{4}$ & $\mathrm{KH}_{2} \mathrm{PO}_{4}$ & $\mathrm{CaCl}_{2}$ & $\mathrm{MgSO}_{4}$ & $\mathrm{Fe}_{2}\left(\mathrm{SO}_{4}\right)_{3}$ & $\begin{array}{c}\text { Biomass } \\
(\mathrm{g} / \mathrm{L})\end{array}$ & $\begin{array}{c}\text { Uptake } \\
(\%)\end{array}$ \\
\hline 1 & -1 & -1 & -1 & 1 & 1 & 1 & -1 & 5.019 & 76.558 \\
\hline 2 & -1 & -1 & 1 & 1 & -1 & -1 & 1 & 4.629 & 41.278 \\
\hline 3 & -1 & 1 & -1 & -1 & 1 & -1 & 1 & 4.322 & 50.474 \\
\hline 4 & -1 & 1 & 1 & -1 & -1 & 1 & -1 & 4.844 & 51.979 \\
\hline 5 & 1 & -1 & -1 & -1 & -1 & 1 & 1 & 4.357 & 21.214 \\
\hline 6 & 1 & -1 & 1 & -1 & 1 & -1 & -1 & 6.180 & 99.307 \\
\hline 7 & 1 & 1 & -1 & 1 & -1 & -1 & -1 & 5.738 & 67.529 \\
\hline 8 & 1 & 1 & 1 & 1 & 1 & 1 & 1 & 4.438 & 94.616 \\
\hline 9 & 0 & 0 & 0 & 0 & 0 & 0 & 0 & 4.747 & 50.474 \\
\hline 10 & 0 & 0 & 0 & 0 & 0 & 0 & 0 & 4.742 & 50.976 \\
\hline 11 & 0 & 0 & 0 & 0 & 0 & 0 & 0 & 4.747 & 50.475 \\
\hline
\end{tabular}
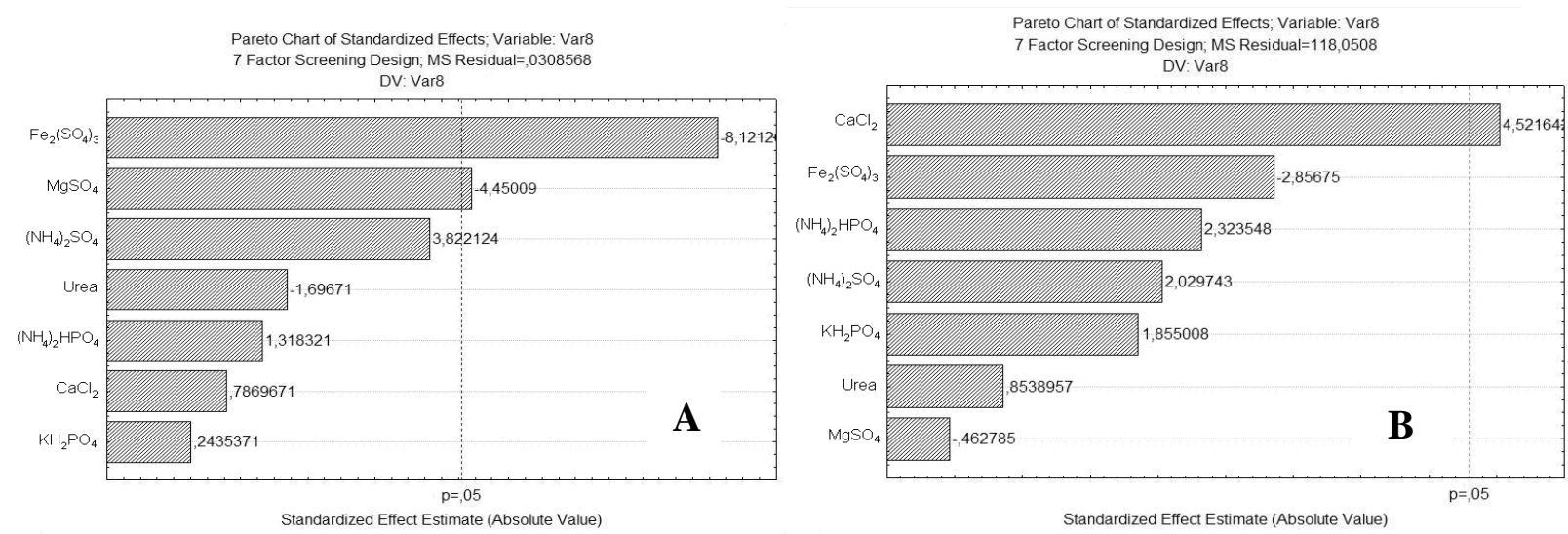

Figure 1 - Pareto chart of biomass production $\left(A ; R^{2}=0,98142\right)$ and copper bioaccumulation (B; $\left.\mathrm{R}^{2}=0,95507\right)$ on $2^{7-4}$ incomplete factorial design with 3 central points.

For biomass production, $\mathrm{Fe}_{2}\left(\mathrm{SO}_{4}\right)_{3}$ and $\mathrm{MgSO}_{4}$ were significant (Fig. 1A) at 5\% $(\mathrm{p}<005)$. According to the Pareto chart, the concentrations of the two significant variables should be lowered in the next step of optimization. However, the concentrations of the two significant factors were low and they were fixed at these levels. Therefore, the choice of variables used in the next step of optimization was performed based on the best results of experiment 6 (Table 4). The variables $\left(\mathrm{NH}_{4}\right)_{2} \mathrm{SO}_{4},\left(\mathrm{NH}_{4}\right)_{2} \mathrm{HPO}_{4}$ and $\mathrm{CaCl}_{2}$ were chosen 
for the next optimization step with the inclusion of molasses concentration $\left({ }^{\circ}\right.$ Brix).

Second step of optimization of chemical conditions - Incomplete factorial design type $2^{4-1}$ with three central points

A second incomplete factorial design of type $2^{4-1}$ with three central points was applied in order to study the influence of four variables $\left(\left(\mathrm{NH}_{4}\right)_{2} \mathrm{SO}_{4}\right.$, $\left(\mathrm{NH}_{4}\right)_{2} \mathrm{HPO}_{4}, \mathrm{CaCl}_{2}$ and ${ }^{\circ}$ Brix $)$ on biomass production with copper accumulation. The highest copper bioaccumulation occurred with $\left(\mathrm{NH}_{4}\right)_{2} \mathrm{SO}_{4}$, which was the main significant factor $(\mathrm{p}<0.05)$ presenting a negative effect (Fig. 2). For biomass production, the concentration of molasses was significant $(\mathrm{p}<0.05)$ with a positive effect. The highest copper bioaccumulation occurred in experiment $1(99.3 \%)$ with a biomass production of $7.9 \mathrm{~g} / \mathrm{L}$ (data not shown). Thus, for the next step of optimization, levels of both the sinificant factors, $\left(\mathrm{NH}_{4}\right)_{2} \mathrm{SO}_{4}$ and molasses concentration ( $\left.{ }^{\circ} \mathrm{Brix}\right)$, were tested in order to find the best results for the two responses (biomass production and bioaccumulation of copper).
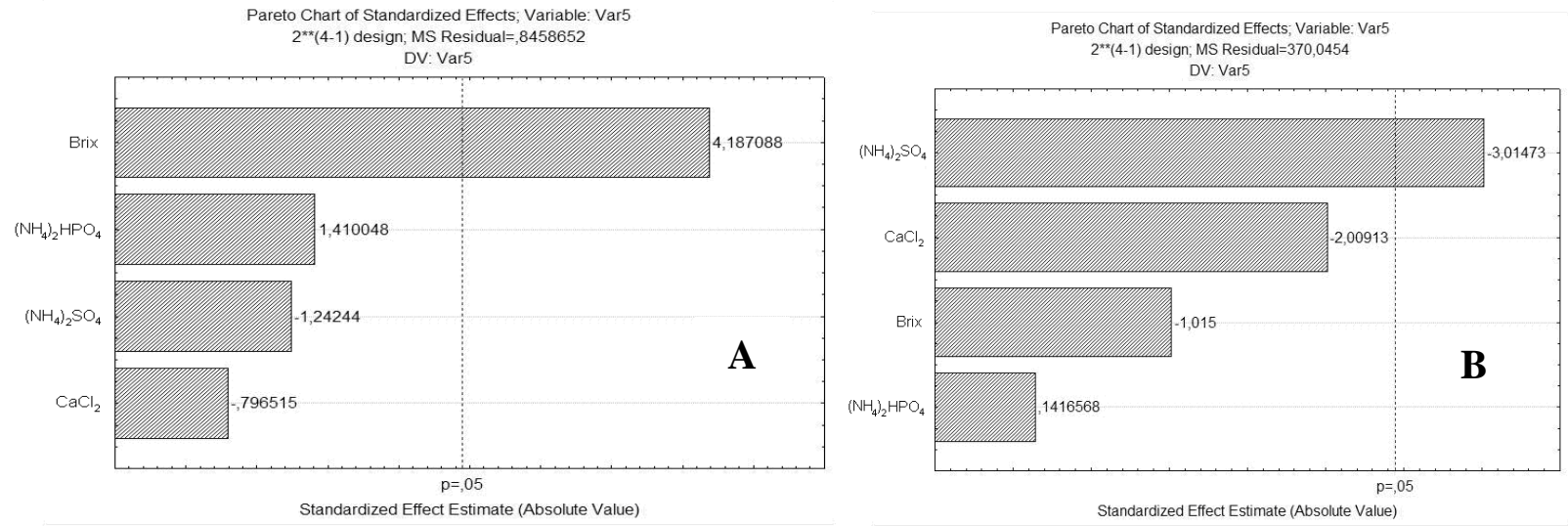

Figure 2 - Pareto chart of biomass production $\left(A ; R^{2}=0,98338\right)$ and copper bioaccumulation (B; $\left.\mathrm{R}^{2}=90621\right)$ of $24-1$ incomplete factorial design.

Third step of the optimization of chemical conditions - Rotational Central Composite Experimental Design - DCCR

The two factors, $\left(\mathrm{NH}_{4}\right)_{2} \mathrm{SO}_{4}$ and ${ }^{\circ} \mathrm{Brix}$ were studied at five levels in a rotational central composite experimental planning - DCCR with eight assays and three central points. The best results (Table 5) were obtained in the central point. In these conditions, the biomass yield was 13.4 $\mathrm{g} / \mathrm{L}$ and copper bioaccumulation on average was $95.03 \%$.

Table 5 - Copper bioaccumulation and biomass production during optimization of chemical factors rotational central composite experimental design (DCCR).

\begin{tabular}{ccccc}
\hline \multirow{2}{*}{ Experiment } & \multicolumn{2}{c}{ Independent Variables } & \multicolumn{2}{c}{ Response Variables } \\
\cline { 2 - 5 } & $\mathbf{( N H}_{\mathbf{4}} \mathbf{S}_{\mathbf{2}} \mathbf{S O}_{\mathbf{4}}$ & $\mathbf{0}^{\mathbf{B R I X}}$ & Biomass $\mathbf{( g / \mathbf { L } )}$ & Uptake (\%) \\
\hline 1 & -1 & -1 & 6,666 & 60,022 \\
2 & 1 & -1 & 6,106 & 59,558 \\
3 & -1 & 1 & 5,944 & 45,326 \\
4 & 1 & 1 & 6,956 & 52,287 \\
5 & $-1,41421$ & 0 & 6,618 & 47,956 \\
6 & 1,41421 & 0 & 6,050 & 49,658 \\
7 & 0 & $-1,41421$ & 6,886 & 58,320 \\
8 & 0 & 1,41421 & 6,962 & 60,796 \\
9 & 0 & 0 & 13,628 & 95,293 \\
10 & 0 & 0 & 13,132 & 95,757 \\
11 & 0 & 0 & 13,432 & 94,055 \\
\hline
\end{tabular}


The squared terms of the factors $\left(\mathrm{NH}_{4}\right)_{2} \mathrm{SO}_{4}$ and ${ }^{\circ}$ Brix were significant at $\mathrm{p}<0.05$. The interaction between the two linear terms was also significant. These observations were valid for biomass production (Fig. not shown) and for copper bioaccumulation according to Figure 3A. Figure

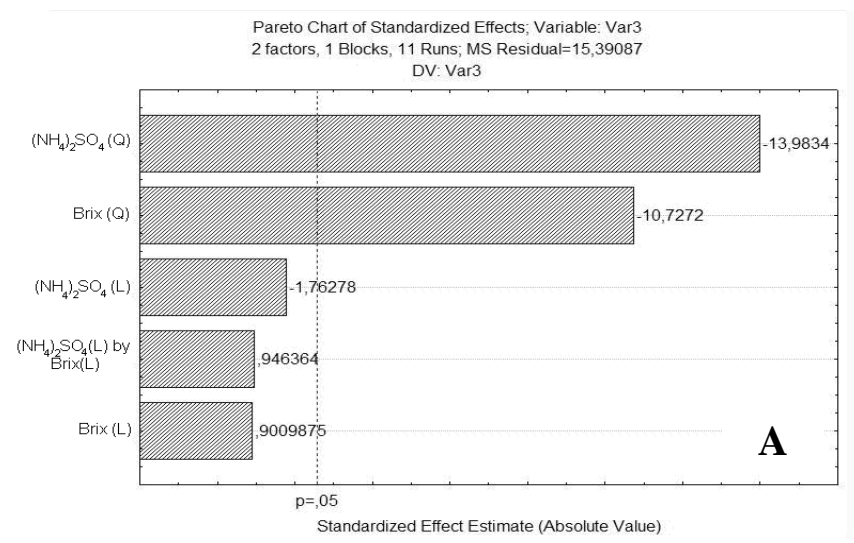

3B shows the optimal region for copper bioaccumulation by $C$. pelliculosa BARU05 $\left(\mathrm{R}^{2}=0.9888\right)$. This region corresponded to $2 \mathrm{~g} / \mathrm{L}$ of $\left(\mathrm{NH}_{4}\right)_{2} \mathrm{SO}_{4}$ and $7.5{ }^{\circ}$ Brix (concentration of molasses).

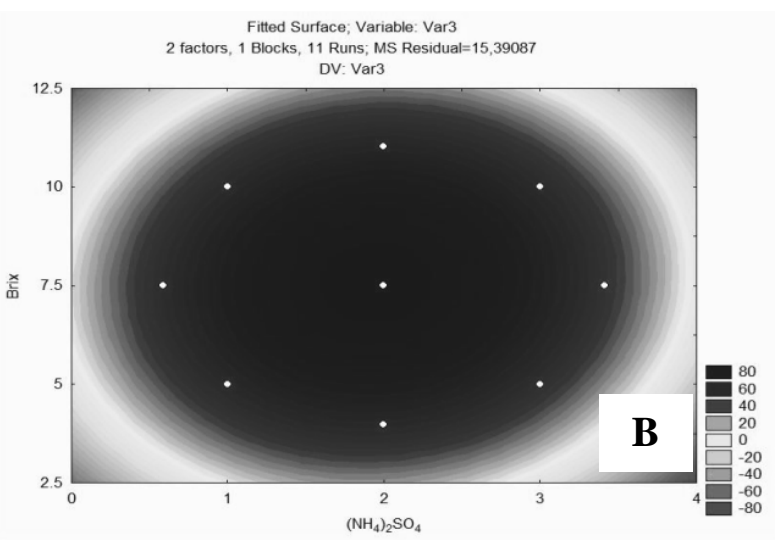

Figure 3 - Pareto chart (A) and response surface (B) of copper bioaccumulation generated by the rotational central composite experimental design (DCCR).

It has been reported that the metal biosorption capacity by some microorganisms can be optimized by the choice of factors such as chemical and physical experimental conditions, which will influence the formation of biomass and, consequently, its accumulation (Gadd, 1993; Brady et al., 1994).

After all the steps of optimization, the copper accumulation was $95.04 \%$ and the biomass produced was $13.397 \mathrm{~g} / \mathrm{L}$, representing an increase of $8.17 \%$ of copper bioaccumulation and $34.67 \%$ of biomass production compared to the process performed before the optimization. Finally, the optimal conditions for copper bioaccumulation were as $\mathrm{pH} 6$, inoculums $7.5 \%$, and incubation at $30^{\circ} \mathrm{C}$. The best chemical conditions were $10^{\circ}$ Brix cane molasses supplemented with $2 \mathrm{~g} / \mathrm{L}$ $\left(\mathrm{NH}_{4}\right)_{2} \mathrm{SO}_{4}$ and $3 \mathrm{~g} / \mathrm{L}\left(\mathrm{NH}_{4}\right)_{2} \mathrm{HPO}_{4}$.

\section{Kinetics of biomass production with copper bioaccumulation in a STR bioreactor Batch fermentation}

Figure 4 shows the kinetic study of biomass production with copper bioaccumulation in the 10 $-\mathrm{L}$ bioreactor in the batch operation. The production of biomass reached $38.85 \mathrm{~g} / \mathrm{L}$ and copper accumulation was $91.98 \%$ in $24 \mathrm{~h}$ of fermentation. An increase of $190 \%$ of biomass production was obtained which was probably due to the better control of process variables and, mainly due to a more intensive aeration which stimulated the growth. Similar results were reported by Rajoka et al., (2006) who attested the importance of intensive aeration (30\% dissolved oxygen) to increase the biomass production.
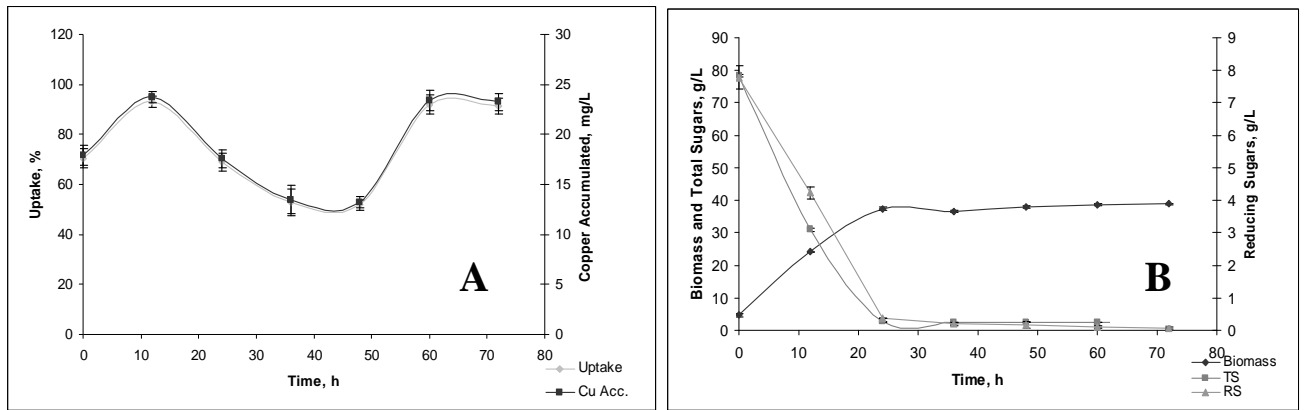

Figure 4 - Copper accumulation ( $\mathrm{Cu}$ Acc.) and copper uptake (A) and biomass production and consumption of total (TS) and reducing (RS) sugars (B) during batch fermentation. 


\section{Fed-batch fermentation}

After the batch process, the kinetics of biomass production with copper bioaccumulation was conducted in fed-batch in order to verify the influence of the supplementation of the medium on biomass production. The production of biomass reached $57.54 \mathrm{~g} / \mathrm{L}$ and bioaccumulation yield reached $100 \%$ (Fig. 5) after almost $48 \mathrm{~h}$ of fermentation that represented a gain of $48 \%$ on biomass production. In this case, it would be interesting to make further tests with higher concentrations of copper in the medium, so as to study if $C$. pelliculosa BARU 05 could bioaccumulate higher levels of the metal, after a significant adaptation to copper in the medium.
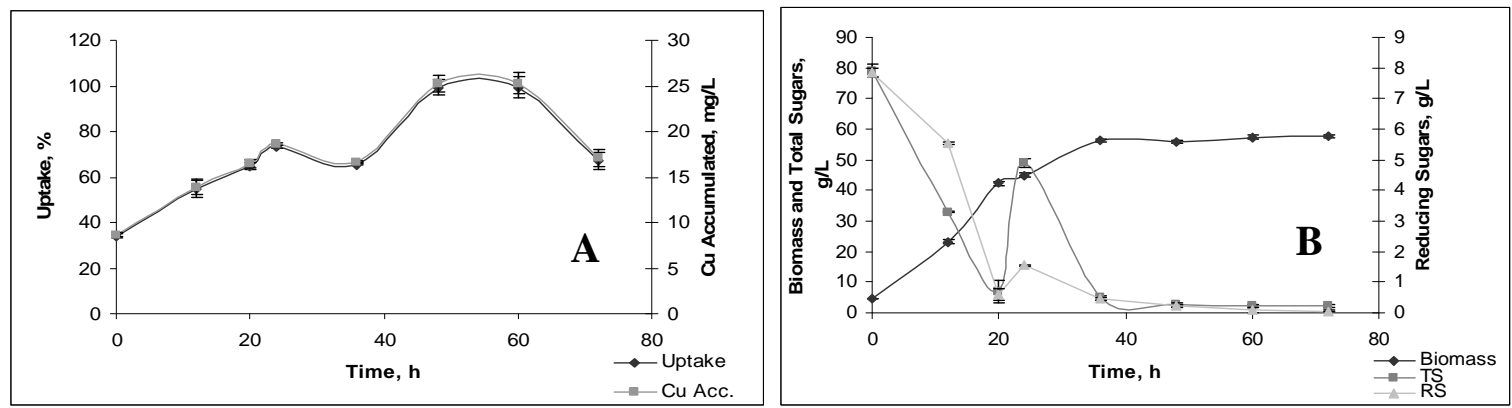

Figure 5 - Copper accumulation $(\mathrm{Cu}$ Acc.) and copper uptake $(\mathrm{A})$ and biomass production and consumption of total (TS) and reducing (RS) sugars (B) during the kinetic in fed-batch fermentation.

Furthermore, high concentrations of biomass represent high concentrations of protein. In this case, biomass had $49 \%$ protein. Menezes and Salles (1976) obtained $48.6 \%$ protein and comparable result to the present study. One of the quality requirements in the specification of dry yeast for animal feed is the minimum percentage of crude protein $(35-40 \%)$ (Leimer, 2005). Thus, the biomass produced by $C$. pelliculosa BARU05 could be considered suitable and within the range of quality requirements.

\section{CONCLUSIONS}

C. pelliculosa BARU 05 demonstrated good capacity to grow in sugar cane molasses and accumulated copper. The batch process resulted $38.85 \mathrm{~g} / \mathrm{L}$ of biomass and $91.98 \%$ copper accumulation in $24 \mathrm{~h}$ of fermentation. The fedbatch process resulted $57.54 \mathrm{~g} / \mathrm{L}$ of biomass and $100 \%$ of copper bioaccumulation. The process for biomass production with copper bioaccumulation by $C$. pelliculosa BARU05 presents a number of advantages, including the low cost of raw material (sugarcane molasses). The use of agro-industrial residues such as soybean molasses, cane molasses, among others, in fermentation helps the development of an environmentally-friendly and attractive process in terms of cost-benefit. The obtained product could be used as an additive in feed for monogastric animals.

\section{ACKNOWLEDGMENTS}

This work was financially supported by CAPES PROF and CAPES REUNI.

\section{REFERENCES}

Alberton, L. R., Vandenberghe, L. P. S., Assman, R., Fendrich, R. C., Leon, J. R., Soccol, C. R. (2009), Xylanase production by Streptomyces viridosporus T7A in submerged and soli-state fermentation using agroindustrial residues. Braz. Arch. Biol. Technol., 52, 171180

Angel R. N. Villavicencio, Ernani S. Sant'Anna, Regina C. O. T. (2000), Produção de Lactobacillus plantarum em Melaço de Cana-de-açúcar. Braz. Arch. Biol. Technol., 43, 119-124

Association of Official Analytical Chemists (AOAC). (1997), Official Methods of Analysis. 16 ed. Washington,

Brady D., Stoll A., Duncan J. R. (1994), Biosorption of heavy metal cations by non-viable yeast biomass. Environ. Technol., 15, 429-438

Cazetta, ML, Celligoi, M. A. P. C, Buzato, J. B., Scarmino, I. S. (1997), Fermentations of molasses by Zymomonas mobilis: effect of temperature and sugar concentration on ethanol production. Bioresour. Technol., 98, 2824-2828, 2007 
Celligoi, M. A. P. C.; Angelis, D. F. de and Buzato J. B. (1997), Application of Sugar-Cane Molasses in the Production of Lipids by Yeast. Braz. Arch. Biol. Technol., 40, $693-698$

Colwell, R. Microbial diversity: the importance of exploration and conservation. J. Ind. Microbiol. Biotechnol., 18, 302-307

Dönmez, G., Aksu, Z. (1999), The effect of copper (II) ions on the growth and bioaccumulation properties of some yeasts. Process Biochem, 35, 135-142

Eaton, A. D., Clesseri, L.S., Greenberg, A. E. (1995), Standard methods for the examination of water and wastewater. $19^{\text {th }}$ ed. New York, Washington: American Public Health Association

Gadd, G. M. (1993), Interactions of fungi with toxic metals. New Phytol., 124, 25-60

Gönen, F., Aksu, Z. (2008), Use of response surface methodology (RSM) in the evaluation of growth and copper(II) bioaccumulation properties of Candida utilis in molasses medium. J. Hazard. Mater., 154, 731-738

Hauschild, L., Lovatto, P. A., Carvalho, A. D., Andretta, I., Lehnen, C. R. (2008), Relação do zinco e cobre plasmáticos com componentes nutricionais $\mathrm{e}$ desempenho de leitões: uma meta-análise. R. Bras. Zootec., 37, 427-432

Hisano, H., Barros, M. M., Pezzato, L. E. (2007), Levedura e zinco como pró-nutrientes em rações para tilápia-do-nilo (Oreochromis niloticus): aspectos hematológicos. Boletim do Instituto de Pesca, 33, 35-42

Hunter, C. (1998), The value of microbial diversity. Curr. Opin. Microbiol., 1, 278-285.

Leimer, K. H. (2005), Aproveitamento de Derivados de Levedura em Alimentação Humana e Animal. In: Fórum de agronegócios: cana-de-açúcar aplicações em biotecnologia. Campinas

Mantelatto, P. E. (2005), Estudo do processo de cristalização de soluções impuras de sacarose de canade-açúcar por resfriamento. Dissertação de MestradoUFSCAR, São Carlos

Marques, A. P., Riet-Correa, F., Soares, M. P., Ortolani, E. L., Giuliodori, M. J. (2003), Mortes súbitas em bovinos associadas à carência de cobre. Pesq. Vet. Bras., 23, 2132

Mcdowell, L. R. (1992), Minerals in animal and human nutrition. San Diego: Academic Press

Menezes, T. J. de B., Sales, A. M. (1976), Produção de biomassa protéica de mandioca. Campinas: Colet. Ital (Inst. Tec. Aliment.), 7,139-146

Ministério da Agricultura Pecuária e Abastecimento (2009), Projeções do agronegócio - Brasil 2008/09 a 2018/19. Assessoria de Gestão Estratégica, Brasília

Moraes, S. S., Tokarnia, C. H., Döbereiner, J. (1999), Deficiências e desequilíbrios de microelementos em bovinos e ovinos em algumas regiões do Brasil. Pesq. Vet. Bras., 19, 23-28

Moro, A. M., Grotto, D., Bulcão, R., Pomblum, V. J., Bohrer, D., Carvalho, L. M, Oliveira. S., Garcia, S. C. (2007), Quantificação laboratorial de cobre sérico por espectrofotometria Vis comparável à espectrometria de absorção atômica com chama. J. Bras. Patol. Med. Lab., 43, 251-256
Nelson, N. (1944), A fotometric adaptation of Somogyi method for the determination of glucose. J Biol Chen, 153, 375-380

Ortolani, E. L. (2002), Macro e microelementos. In: Spinosa, H. S.; Górniak, S. L.; Bernardi, M. M. Farmacologia aplicada à medicina veterinária. 3.ed. São Paulo: Guanabara Koogan S.A. p.641-651

Rajoka, M. I., Khan, S. H., Jabbar, M. A., Awan, M. S., Hashmi, A. S. (2006), Kinetics of batch single cell protein production from rice polishings with Candida utilis in continuously aerated tank reactors. Bioresour. Technol., 97, 1934-1991

Rodrigues, C., Vandenberghe, L. P. S., Teodoro, J., Oss, J. F., Pandey, A., Soccol, C. R. (2009), A new alternative to produce gibberelic acid by solid-state fermentation. Braz. Arch. Biol. Technol., 52, 181-188

Rodrigues, M. I, Iemma, A. F. (2005), Planejamento de experimentos e otimização de processos: uma estratégia seqüencial de planejamentos. Ed. Casa do Pão

Roepecke, C. B. S., Vandenberghe, L. P. S., Soccol, C. R. (2011), Optimized production of Pichia guilliermondii biomass with zinc accumulation by fermentation. Anim. Feed Sci. Technol. (Print), 163, 33-42.

Romeiro, R. S. (2001), Métodos em Bacteriologia de Plantas. Viçosa: UFV

Rubel, R. Produçăo de compostos bioativos de Ganoderma lucidum por fermentaçăo em estado sólido: avaliaçăo da açăo antitumoral, imunomoduladora e hipolipidęmica. Curitiba: Federal University of Paraná; PhD Thesis; 2006

Sella, S. R. R., Guizelini, B. P., Vandenberghe, L. P. S., Medeiros, A. B. P., Soccol, C. R. (2009), Lab-scale production of Bacillus atrophaeus spores by SSF in different types of bioreactors. Braz. Arch. Biol. Technol., 52, 159-170

Stehlik-Tomas, V., Zetic, V. G., Stanzer, D., Grba, S., Vahcic, N. (2004), Zinc, cooper and manganese enrichment in yeast Saccharomyces cerevisiae. Food Technol. Biotechnol., 42,115-120

Sucupira, F. S., Fuentes, M. F. F., Freits, E. R., Braz, N. M. (2007), Alimentação de codornas de postura com rações contendo levedura de cana-de-açúcar. Cienc. Rural, 37, 528-532

Vasquez, E. F. A., Herrera, A. P. N., Santiago, G. S. (2001), Interação cobre molibdênio e enxofre em ruminantes. Cienc. Rural, 31, 1101-1106

Valduga. E., Valério, A., Treichel, H., Lucio, M. D., Jacques, R. A., Fúrigo-Júnior, A. (2007), Prétratamentos de melaço de cana-de-açúcar e água de maceração de milho para bioprodução de caratenóides. Quím. Nova, 30, 1860-1866.

Received: April 05, 2010; Revised: September 03, 2010; Accepted: March 22, 2011. 